\title{
Ministry Orientation Course As A Christian Education Provider In GBI Medan
}

\author{
Parulian Siagian \\ \{grantsam72ps@gmail.com \\ Doctor of Christian Education, Pelita Kebenaran Bible College
}

\begin{abstract}
Along with the current development and by observing the church members' necessity to grow in education, the existence of the Department of Ministry Orientation Course has become really important. According to that, the writer performed a research to observe how the Department of Ministry Orientation Course has contributed to Christian education in Medan Plaza Bethel Church. By having interviewed related parties, it is clear that the existence of the Department of Ministry Orientation Course has contributed significantly to Christian education. The increasing number of participants in the Ministry Orientation Course from year to year has shown the enthusiasm of people to be educated in this course. In 2017, 445 participants have been graduated, in 2018, 531 participants have been graduated and until this year 644 participants have been graduated. The increasing number of participants has been the evidence that church members have regarded the Department of Ministry Orientation Course as the space to produce Christ-like disciples.
\end{abstract}

Key Words: The Department of Ministry Orientation Course, Christian Education, Discipleship

\section{Introduction}

Education is not only discussing the academic grades. The value of human self-esteem cannot be measured by academic grades. Education is generally based on knowledge and experience has happened in the history concept and is generally pioneered by education figures. However, Christian education is based on the bible truth so that church members are not expected to experience stagnation. In order to avoid stagnation, church members have to be educated. The results are the growth of church members in quantity and quality. Church has to comprehend the importance of the education goal because the goal is to bring church members to have more growing lives. According to Limatula Longkumer, "Education means to develop the full potentialities in an individual life." It means that the orientation of education is to develop the potentials of church members in order to become people of faith. Christian education is the vital area in church stewardship. This is based on God's Word mentioning that Christian education has acquired special emphasis in the Old Testament and the New Testament. "It is precisely mentioned that church has the responsibility for the education or the improvement of the church members. The final analysis of the Great Message if the message to educate (Matthew 28:19-20; Acts 2:42)."

The writer has paid attention that Christian education is a really important stewardship in light of church has to exist to play the part of educating the church members. All departments 
of church are really significant, however, without church cannot grow healthily without Christian education. The Department of Ministry Orientation Course is Christian education based on the bible which is organized by Medan Plaza Bethel Church .There are two basic reasons of naming this department 'the Department of Ministry Orientation Course':

a. Stay in the vision of leading passive church members to become active church members which means God is leading and will lead church members to serve actively anywhere.

b. Keep giving the practical meaning of life in order to meet the need of church members in the growing professional world.

One of the requirements to serve in Medan Plaza Bethel church is the certificate of graduation of Ministry Orientation Course. The Department of Ministry Orientation Course has the responsibility for building the church members and preparing them to grow higher. The vision of Department of Ministry Orientation Course is to prepare the church members to serve other people.

\section{Research Method}

This research is a qualitative research and the data are obtained through descriptive research. This research method is selected due to its flexibility and focus on the research subjects.

\subsection{Population}

The population of this research is the number of the church members, 45,000 people. The data are obtained from the chief of staff of Medan Plaza Bethel Church.

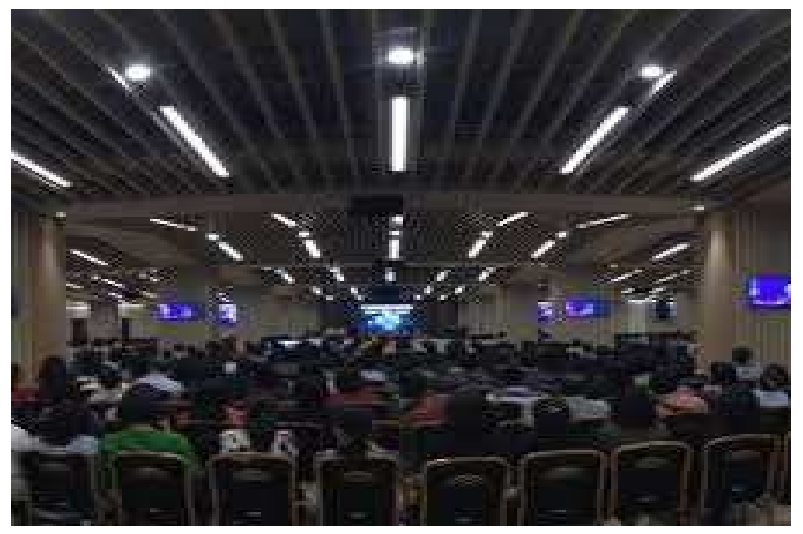

Fig. 1. The Church Members of Medan Plaza Bethel Church

\subsection{Data Collection}

The data are collected from the office of Department of Ministry Orientation Course Medan Plaza Bethel Church. The researcher has directly obtained the data from the relevant resources regarding the number of parcipants in Ministry Orientation Course in the past three years. 


\section{Result and Discussion}

Curriculum plays an important part in arousing interest in joining one course. It is simply stated that curriculum is about the teaching material, the whole resources, and the experiences in teaching and learning situation in order to obtain the objectives. The curriculum of the Ministry Orientation course is stated in three handbooks of teaching consisting of KOM 100, KOM 200 and KOM 300. The writer has tried to compiled the teaching materials from the basic lesson (KOM 100), the study of characters (KOM 200), and the lessons to build the spiritual depth (KOM 300) and obtained the essence of the course stated in the table below.

Table 1. The Essence of the Teaching Material of Ministry Orientation Course

\begin{tabular}{ccc}
\hline No. & The Essence & Series \\
\hline The Foudation of Christianity & 100 \\
The Relationship with God & 100 \\
Characters & 200 \\
The Knowledge of Bible & 200 \\
Stewardshp & 200 \\
Blessing & 300 \\
God's Coming & 300 \\
\hline
\end{tabular}

By referring to the bible as the resource of Christian education, the whole teaching materials are sufficient for the disciples. Disciples are the same as students, people who are studying and being taught. Students are the most essential part in teaching and learning process because without students there are no one to be taught and study. According to Stephen Tong, "Why are students really important? Because human beings are the only creature who can understand the truth, are able to relate themselves to the truth and are formed by the truth itself." The word students used in this discussion is "disciple" which refers more to discipleship. Even though students can study and be taught but it does not mean that students are the objects. Students must be able to study for themselves so that they can achieve their goals and study needs.

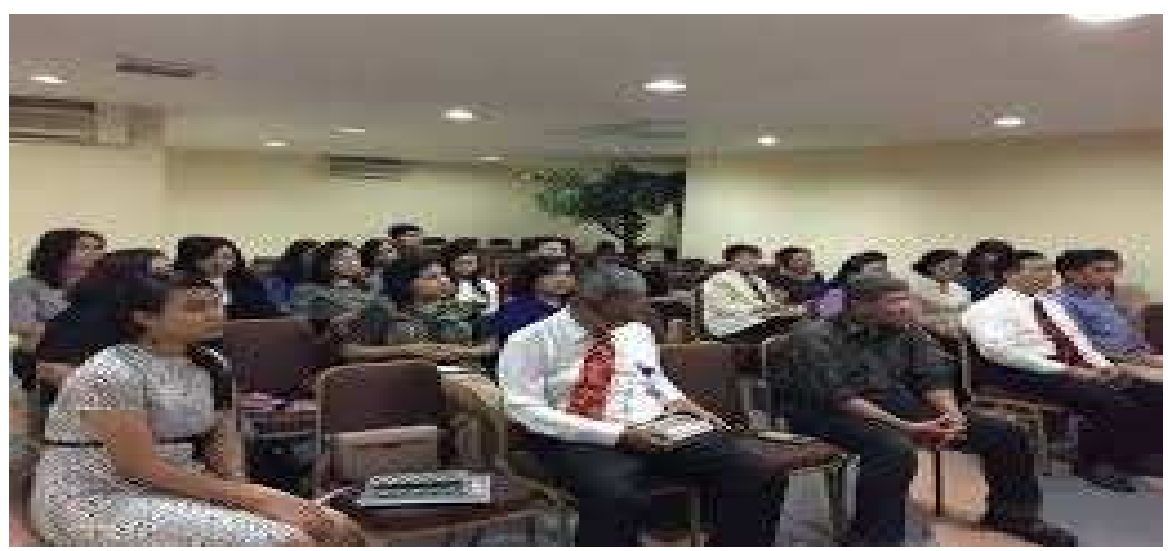

Fig. 2. The Situation of the Class of Ministry Orientation Course 
Since the opening of Ministry Orientation Course, the classes have been full of participants and for the past three years the number of participants have increased more.

Table 2. The Recapitulation of the graduates for the Past Three Years

\begin{tabular}{ccc}
\hline No. & Year & The Number of Graduates \\
\hline 1. & 2017 & 445 \\
2. & 2018 & 531 \\
3. & 2019 & 644 \\
\hline
\end{tabular}

The Department of Ministry of Orientation Course has given a significant impact to disciple the church members. In 2018 the participants of the course had increased 86 people from 2017. In 2019 until this article was written the participants have also increased 113 people.

\section{Conclusion}

Looking at the enthusiasm of the church members to be discipled in the Ministry of Orientation Course from year to year, the writer can conclude that the existence of the Department of Ministry Orientation Course is beneficial. It is clear that the Department of Ministry Orientation Course is the place to produce Christ-like disciples . The writer expects that this article can be an input for the staff of the Department of Ministry Orientation Course to work harder and better to organize this department.

\section{References}

[1] Sean Covey, The 7 Habits of Highly Effective Teens, (Jakarta, Dunamis Publishing, 1917)

[2] Tim Penyusun, Kamus Besar Bahasa Indonesia (Jakarta: Balai Pustaka, 1990) s.v. "Kualifikasi"

[3] John M, Echols dan Hassan Shadily, Kamus Bahasa Inggris-Indonesia (Jakarta: Gramedia, 1983) s.v. "Qualification"

[4] Redja Mudyahardjo, Pengantar Pendidikan (Jakarta: Raja Grafindo Persada, 2009)

[5] Limatula Longkumer, Christian Education for Adult in Tribal Context, (Jorhat Assam Eastern Theological Collage 1998)

[6] B.S. Sidjabat, Strategi Pendidikan Kristen, (Yogyakarta: Andi, 1999)

[7] Kenneth O. Gangel, Christian Education: Its History and Philosophy (Chicago: Moody Press, 1983)

[8] KOM seri 100 Pencari Tuhan, Divisi Pengajaran Gereja Bethel Indonesia.

[9] Winona Walworth, Introduction to Biblical Christian Education (Chicago Moody Biblical Institute, 1981)

[10] Stephen Tong, Arsitek Jiwa (Surabaya: Lembaga Reformed Injili Indonesia,1993)

[11] Sugiono, Metode Penelitian Pendekatan Kuantitatif, Kualitatif dan R\&D, (Bandung: Alfa Beta

[12] 2009).

[13] Wirawan, Evaluasi: Teori, Model, Metodologi, Standar, Aplikasi dan Profesi. pp. 21.( Raja Grafindo Persada, Jakarta 2016). 